\title{
PENGARUH KECERDASAN EMOSIONAL DAN KOMITMEN ORGANISASI TERHADAP KINERJA KARYAWAN PADA PT. RISMAWAN PRATAMA BERSINAR SUKABUMI
}

\author{
Deri Firmansyah $^{1}$, Galih Raspati ${ }^{2}$, Erwin Rinaldy Hidayat ${ }^{3}$ \\ Fakultas Ekonomi, STIE PASIM Sukabumi \\ deri@stiepasim.ac.id,galihrespati@stiepasim.ac.id,e.rinaldy@yahoo.co.id
}

\begin{abstract}
The purpose of this study was to determine the effect of emotional intelligence and organizational commitment on employee performance at PT. Rismawan Pratama Shining Sukabumi. The design in this study uses a survey method with descriptive-quantitative approach and associative methods. To test the analysis of the research instruments used validity test, reliability test and classic assumption test, then to test statistical analysis and relationship analysis used Pearson product moment correlation, coefficient of determination, multiple linear regression and to test the hypothesis used the $t$ test and $F$ test. Based on the results of research that has been done, it can be seen that simultaneously emotional intelligence and organizational commitment significantly influence employee performance. By comparing $F_{\text {count }}$ with $F_{\text {table }}(183.9719>3.10)$, it means that $H_{0}$ is rejected and $H_{1}$ is accepted, so the research hypothesis proposed in this study is proven that emotional intelligence and organizational commitment together (simultaneously) affect the performance of employees. The magnitude of the contribution of the influence of emotional intelligence and organizational commitment to employee performance by $80.5 \%$, while the remaining $19.5 \%$ is influenced by variables not examined.
\end{abstract}

Keywords: Emotional Intelligence, Commitment, Organization, and Performance Employee

\section{PENDAHULUAN}

\subsection{Latar Belakang}

Hasil kerja yang telah dicapai oleh karyawan dalam suatu organisasi menunjukan cerminan berhasil atau tidaknya suatu organisasi, sehingga organisasi senantiasa menuntut agar para karyawannya mampu menampilkan kinerja yang maksimal karena baik buruknya capaian kinerja karyawan akan berpengaruh pada peningkatan kinerja dan kesuskesan organisasi secara keseluruhan (Indra Gunawan, H. Sutadji, 2014). Kinerja karyawan tidak hanya dilihat dari kemampuan yang sempurna, tetapi juga kemampuan menguasai dan mengelola diri sendiri serta kemampuan dalam membina hubungan kerja dengan orang lain. Kemampuan tersebut oleh Daniel Goleman disebut dengan Emotional Intelegence atau kecerdasan emosi. Goleman melalui penelitiannya mengatakan bahwa kecerdasan emosi dapat menyumbang $80 \%$ dari faktor penentu kesuksesan seseorang di dalam suatu organisasi, sedangkan $20 \%$ yang ditentukan oleh IQ (intelligence Quotient)(Goleman, 2000). Kecerdasan emosi yang dimasukkan dalam sistem kompetensi untuk setiap posisi yang telah dibuat sebenarnya bisa dikembangkan untuk banyak fungsi dalam SDM, mulai dari rekruitmen, pelatihan dan pengembangan karier hingga penilaian kinerja. Sehingga jika hal tersebut dilakukan, maka sistem manajemen manajemen sumber daya manusia mampu memotivasi pegawainya untuk mengembangkan kecerdasan emosinya, sehingga bukan hanya kompetensi teknis yang berkembang tetapi juga produktivitas dan kinerjapun ikut meningkat. Konsep kecerdasan emosional merupakan 
fenomena yang masih baru dalam dunia psikologi industry dan organisasi, akan tetapi penggunaanya dalam dunia kerja sangat dibutuhkan. Karena hal ini akan berimbas pada kondisi karyawan tersebut dalam menentukan kepuasan kerjanya yang didukung dengan komitmen organisasi.Kecerdasan emosional sangat dipengaruhi oleh beberapa faktor, baik faktor Psikologis maupun pelatihan emosi. Faktor psikologi Faktor ini akan membantu individu dalam mengelola, mengontrol, mengendalikan dan mengkoordinasikan keadaan emosi agar termanifestasi dalam perilaku secara efektif sedangkan faktor pelatihan emosi Kegiatan yang dilakukan secara berulang-ulang akan menciptakan kebiasaan, dan kebiasaan rutin tersebut akan menghasilkan pengalaman yang berujung pada pembentukan nilai (value).

Faktor lain yang dapat meningkatkan kinerja adalah adanya komitmen organisasi. Pegawai dengan komitmen yang tinggi diharapkan mampu menunjukkan kinerja yang optimal. Seseorang yang bergabung dalam organisasi pada sebuah organisasi dituntut memiliki komitmen dalam dirinya. Sebagai definisi yang umum, Luthansmendefinisikan bahwa komitmen organisasional sebagai sikap yang menunjukkan "loyalitas" pegawai dan merupakan proses berkelanjutan bagaimana seorang anggota organisasi mengekspresikan perhatian mereka kepada keberhasilan dan kebaikan organisasinya(Indra Gunawan, H. Sutadji, 2014). Rendahnya komitmen menimbulkan persoalan bagi pihak organisasi. Komitmen (keikatan) terhadap organisasi seolah-olah merupakan komuditas "mahal" tapi penting bagi organisasi tersebut. Komitmen yang rendah mencerminkan kurangnya tanggung jawab seseorang dalam menjalankan tugasnya. Peningkatan kinerja harus didukung dengan pengelolaan kecerdasan emosional dan memiliki komitmen organisasi yang baik sehingga dapat memberikan motivasi atau gairah kerja baru bagi karyawan berbagai perusahaan termasuk salah satunya adalahPT. Rismawan Pratama Bersinar Sukabumi. Komitmen organisasi mempunyai peranan dan pengaruh dalam kegiatan organisasi, baik itu pekerjaan maupun kecerdasan emosional dalam bekerja komitmen organisasi merupakan semangat karyawan dalam bekerja dan menghabiskan waktu sepanjang hari, tentu saja ini akan sangat berpengaruh kepada kinerja karyawan. Masalah yang harus dihadapi seperti suasana dan kondisi kerja dan hubungan karyawan. Komitmen organisasi kadang menjadi faktor penentu tujuan dan target kinerja karyawan, dimana karyawan banyak menghabiskan waktu sehari hari. Kinerja merupakan suatu pencapaian berhasil atau tidaknya tujuan organisasi yang telah ditetapkan sebelumnya. Informasi tentang kinerja karyawan adalahfeedback yang sangat penting yang digunakan untuk mengevaluasi apakah proses kerja dan kinerja yang dilakukan karyawan dalam suatu organisasi selama ini sudah sejalan dengan tujuan yang diharapkan atau belum (Rani, Mayasari, 2016).

Organisasi pada dasarnya dijalankan oleh manusia maka kinerja sesungguhnya merupakan perilaku manusia dalam memainkan peran yang mereka lakukan di dalam suatu organisasi untuk memenuhi standar perilaku yang telah ditetapkan agar membuahkan hasil dan tindakan yang diinginkan. Berdasarkan uraian dan fenomena di atas penulis tertarik untuk mencoba mengkaji lebih jauh permasalahan ini melalui penelitian yang berjudul: "Pengaruh Kecerdasan Emosional dan Komitmen Organisasi Terhadap Kinerja karyawan Pada PT. Rismawan Pratama Bersinar Sukabumi“.

\subsection{Rumusan Masalah}

Berdasarkan uraian dari latar belakang di atas, maka dalam penelitian ini peneliti merumuskan permasalahan sebagai berikut:

1. Bagaimana kecerdasan emosional, komitmen organisasi dan kinerja karyawan pada PT. Rismawan Pratama Bersinar Sukabumi

2. Bagaimana pengaruh kecerdasan emosional terhadap kinerja karyawan pada PT. Rismawan Pratama Bersinar Sukabumi 
3. Bagaimana pengaruh komitmen organisasi terhadap kinerja karyawan pada pada PT. Rismawan Pratama Bersinar Sukabumi

4. Bagaimana pengaruh kecerdasan emosional dan komitmen organisasi terhadap kinerja karyawan pada pada PT. Rismawan Pratama Bersinar Sukabumi secara simulan

\subsection{Tujuan Penelitian}

Tujuan dari penelitian ini adalah sebagai berikut :

2. Untuk mengetahui bagaimanakecerdasan emosional, komitmen organisasi dan kinerja karyawan pada PT.Rismawan Pratama Bersinar Sukabumi

3. Untuk mengetahui bagaimana pengaruh kecerdasan emosional terhadap kinerja karyawan pada PT.Rismawan Pratama Bersinar Sukabumi

4. Untuk mengetahui bagaimana pengaruh komitmen organisasi terhadap kinerja karyawan pada pada PT.Rismawan Pratama Bersinar Sukabumi

\section{KAJIAN LITERATUR}

\subsection{Kecerdasan Emosional}

\subsubsection{Definisi Kecerdasan Emosional}

Emosi merujuk pada suatu perasaan dan pikiran yang khas, suatu keadaan biologis dan psikologis dan serangkaian kecenderungan untuk bertindak. Emosi pada dasarnya adalah dorongan untuk bertindak. Biasanya emosi merupakan reaksi terhadap rangsangan dari luar dan dalam diri individu. Sebagai contoh emosi gembira mendorong perubahan suasana hati seseorang, sehingga secara fisiologi terlihat tertawa, emosi sedih mendorong seseorang berperilaku menangis(Goleman, 2000). Definsi lain mengatakan bahwakecerdasan emosional adalah kemampuan, ketrampilan, kapabilitas dan kompetensi non kognitif yang mempengaruhi kemampuan seseorang untuk berhasil dalam menghadapi tuntutan dan tekanan lingkungannya(Robins, 2014). Kecerdasan emosi merujuk pada kemampuan untuk mengenali perasaan kita sendiri dan perasaan orang lain, kemampuan memotivasi diri sendiri dan kemampuan mengelola emosi secara baik pada diri sendiri dan dalam hubungannya dengan orang lain(Goleman, 2000).

\subsubsection{Dimensi Kecerdasan Emosional}

Goleman mengadaptasi lima indikator yang tercakup dalam kecerdasan emosional dari model Solovey dan Meyer(Goleman, 2000), yaitu :

a. Kesadaran Diri

Kesadaran diri adalah mengetahui apa yang kita rasakan pada suatu saat, dan menggunakannya untuk memandu pengambilan keputusan diri sendiri, memiliki tolak ukur yang realistis atas kemampuan diri dan kepercayaan diri yang kuat.

b. Penguasaan Diri

Penguasaan diri adalah menangani emosi sedemikian rupa sehingga berdampak positif kepada pelaksanaan tugas, peka terhadap kata hati dan sanggup menunda kenikmatan sebelum tercapainya sasaran, mampu pulih kembali dari tekanan emosi.

c. Motivasi Diri

Motivasi diri adalah menggunakan hasrat diri yang paling dalam untuk menggerakkan dan menuntun diri menuju sasaran, membantu individu mengambil inisiatif dan bertindak sangat efektif dan untuk bertahan menghadapi kegagalan dan frustasi.

d. Empati 
Empati merupakan kemampuan merasakan apa yang dirasakan oleh orang lain, mampu memahami perspektif mereka, menumbuhkan hubungan saling percaya dan menyelaraskan diri dengan bermacam-macam orang.

e. Keterampilan sosial

Menangani emosi dengan baik ketika berhubungan dengan orang lain dengan cermat membaca situasi dan jaringan sosial; berinteraksi dengan lancar; menggunakan keterampilan-keterampilan ini untuk mempengaruhi dan memimpin, bermusyawarah dan menyelesaikan perselisihan, dan untuk bekerja sama dan bekerja dalam tim.

\subsection{Komitmen Organisasi}

\subsubsection{Definisi Komitmen Organisasi}

Komitmen merupakan kesepakan, kesediaan dan rasa sukarela dari seseorang untuk bertindak dan melaksanakan suatu kegiatan dengan penuh rasa tanggung jawab pada diri sendiri dan pihak lain sebagai bentuk nyata dari kesetiaan atas perjanjian yang telah disepakatinya. Komitmen adalah sikap kesediaan diri untuk memegang teguh visi, misi serta kemauan untuk mengerahkan seluruh usaha dalam melaksanakan tugas. Komitmen karyawan tidak akan tumbuh dengan sendirinya, ada hubungan signifikan antara budaya kerja dengan komitmen karyawan(Robins, 2014). Sedangkan komitmen organisasi merupakan salah satu sikap yang merefleksikan perasaan suka atau tidak suka terhadap organisasi tempatnya bekerja(Robins, 2014). Dengan kata lain komitmen organisasi ialah sikap individu yang tertarik dengan tujuan, nilai dan sasaran organisasi yang ditunjukkan dengan adanya penerimaan individu atas nilai dan tujuan organisasi serta memiliki keinginan untuk berafiliasi dengan organisasi dan kesediaan bekerja keras untuk organisasi sehingga membuat individu betah dan ingin bertahan di organisasi tersebut demi tercapainya tujuan dan kelangsungan organisasi. Komitmen organisasional adalah keinginan anggota organisasi untuk mempertahankan keanggotaannya dalam organisasi dan bersedia berusaha keras bagi pencapaian tujuan orgnaisasi (Sopiah, 2008). Komitmen organisasional mencakup kebanggaan anggota, kesetiaan anggota, dan kemauan anggota pada organisasi.

\subsubsection{Dimensi Komitmen Organsasi}

Komitmen organisasi dipengaruhi oleh tiga komponen sehingga individu memilih tetap atau meninggalkan organisasi berdasarkan norma yang dimilikinya. Komponen tersebut (Robins, 2014), yaitu;

a. Komitmen Afektif (Affective Commitment) : yang cenderung mengacu pada keterikatan emosional, yaitu identifikasi serta keterlibatan seorang karyawan pada suatu organisasi. Komitmen Afektif seseorang akan menjadi lebih kuat bila pengalamannya dalam suatu organisasi konsisten dengan harapan-harapan dan memuaskan kebutuhan dasarnya dan sebaliknya. Goal congruence orientation seseorang terhadap organisasi menekankan pada sejauh mana seseorang mengidentifikasikan dirinya dengan organisasi memiliki tujuan-tujuan pribadi yang sejalan dengan tujuan-tujuan organisasi. Pendekatan ini mencerminkan keinginan seseorang untuk menerima dan berusaha mewujudkan tujuan-tujuan organisasi. Ada suatu jenis komitmen yang berhubungan dengan pendekatan kongruensi tujuan (goal congruence approach), yaitu komitmen afektif (affective commitment) yang menunjukkan kuatnya keinginan seseorang untuk terus bekerja bagi suatu organisasi karena ia memang setuju dengan organisasi itu dan memang berkeinginan melakukannya. Pegawai yang mempunyai komitmen afektif yang kuat tetap bekerja dengan perusahaan karena mereka menginginkan untuk bekerja di perusahaan itu. 
b. Komitmen Berkelanjutan (Continuance Commitment) : Yang mengacu pada keinginan bahwa karyawan dalam berkeinginan meninggalkan perusahaan. Konsep side-bets orientation yang menekankan pada sumbangsih seseorang yang sewaktu-waktu dapat hilang jika orang itu meninggalkan organisasi. Tindakan meninggalkan organisasi menjadi sesuatu yang beresiko tinggi karena orang merasa takut akan kehilangan sumbangan yang mereka tanamkan pada organisasi itu dan menyadari bahwa mereka tak mungkin mencari gantinya.

c. Komitmen Normatif (Normative Commitment) : Cenderung mengacu pada keinginan karyawan untuk tetap dalam organisasi. Komitmen normatif bisa dipengaruhi beberapa aspek antara lain sosialisasi awal dan bentuk peran seseorang dari pengalaman organisasinya.

\subsection{Kinerja Karyawan}

\subsubsection{Definisi Kinerja Karyawan}

Kinerja karyawan merupakan suatu hasil yang dicapai oleh pegawai tersebut dalam pekerjaanya menurut kriteria tertentu yang berlaku untuk suatu pekerjaan tertentu. Kinerja adalah hasil kerja secara kualitas dan kuantitas yang dicapai oleh seorang pegawai dalam melaksanakan tugasnya sesuai dengan tanggung jawab yang diberikan kepadanya(Mangkunegara dalam Supardi, 2016). Pengertian lain menyatakan bahwa kinerja adalah kombinasi dari efektivitas dan efisiensi pada saat melakukan tugas pokok pekerjaan(Robins, 2014)". Sedangkan yang dimaksud dengan Kinerja karyawan adalah hasil kerja yang dapat dicapai oleh seseorang atau sekelompok orang dalam suatu organisasi, sesuai dengan wewenang dan tanggungjawab masing-masing, dalam rangka pencapaian tujuan organisasi yang bersangkutan secara legal, tidak melanggar hukum dan sesuai dengan moral dan etika. Kinerja seorang karyawan baik bila ia mempunyai keahlian (skill) yang tinggi, bersedia bekerja karena diberi gaji atau upah sesuai dengan perjanjian dan mempunyai harapan (expectation) masa depan yang baik(Sinambela, 2019).

\subsubsection{Dimensi Kinerja Karyawan}

Kinerja berasal dari kata Job Performance atauActual Performance adalah hasil kerja secara kualitas dan kuantitas yang dicapai oleh seorang pegawai dalam melaksanakan tugasnya sesuai dengan tanggung jawab yang diberikan kepadanya.

Dimensi kinerja karyawanada empat kategori yang digunakan untuk mengukur tingkat kinerja karyawan secara individual(Sinambela, 2019), sebagai berikut:

1. Kualitas (Quality)

2. Kuantitas (Quantity)

3. Tingkat pengetahuan (Job knowledge)

4. Tingkat ketepatan waktu (Availabilty)(Sinambela, 2019)

\subsection{Pengaruh Kecerdasan Emosional dan Komitmen Organsiasi Terhadap Kinerja Karyawan}

Keberhasilan suatu organisasi sangatlah dipengaruhi oleh kinerja individu karyawan. Setiap organisasi pasti selalu meningkatkan kinerja karyawan untuk mencapai tujuan. Salah satu ukuran kinerja karyawan adalah kemampuan intelektual, yang didukung dengan kemampuan menguasai, mengelola diri sendiri serta membina hubungan dengan orang lain(Fitriastuti, 2013).

Kemampuan memahami dan mengatur orang lain untuk bertindak bijaksana dalam menjalin hubungan terdapat pada kecerdasan emosional(Goleman dalam Fitriastuti, 2013). Orang yang memiliki kecerdasan emosi tinggi akan mampu memahami dirinya sendiri dan emosi orang lain. Orang tersebut dapat memanfatkan pemahaman ini untuk meningkatkan perilaku dan sikapnya dalam menuju arah yang lebih positif, sehingga mampu mengendalikan emosi, lebih termotivasi, merasa 
puas dan mampu mengatasi masalah dengan lingkungan kerja serta kehidupannya(Wong at al, dalam Fitriastuti, 2013).

\subsection{Kerangka Pemikiran}

Berdasarkan uraian di atas, maka dalam penelitian ini penulis menggambarkan konseptual kerangka pemikiran sebagai berikut:

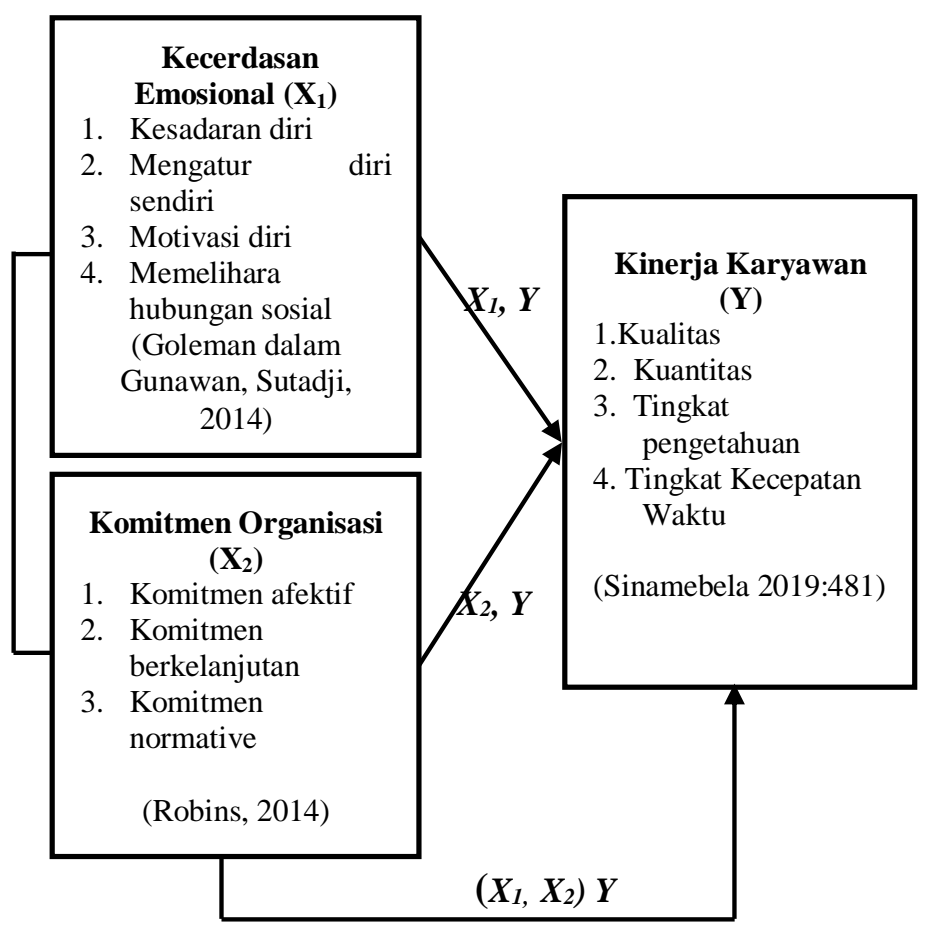

Gambar 2.1

Konseptual Kerangka Pemikiran

\subsection{Hipotesis Penelitian}

Berdasarkan identifikasi masalah, tujuan penelitian dan kerangka pemikiran di atas yang dilandasi atas dasar landasan teoritis, maka dirumuskan hipotesis, sebagai berikut:

1. Kecerdasan emosional, komitmen organisasi dan kinerja karyawan kurang baik pada PT. Rismawan Pratama Bersinar Sukabumi

2. Terdapat pengaruh kecerdasan emosional terhadap kinerja karyawan pada PT. Rismawan Pratama Bersinar Sukabumi

3. Terdapat pengaruh komitmen organsasi terhadap kinerja karyawan pada PT. Rismawan Pratama Bersinar Sukabumi

4. Terdapatpengaruh kecerdasan emosional dan komitmen organsiasi terhadap kinerja karyawan pada PT. Rismawan Pratama Bersinar Sukabumi secara simultan

\section{METODE}

\subsection{Rancangan Penelitian}

Metode merupakan suatu prosedur atau cara ilmiah untuk mengetahui sesuatu. Sedangkan penelitian diartikan sebagai suatu proses pengumpulan dan analisis data secara sistematis dan logis 
untuk mencapai tujuan-tujuan tertentu. Metode penelitian pada dasarnya merupakan cara ilmiah yang digunakan oleh peneliti untuk mendapatkan data dengan tujuan dan kegunaan tertentu(Sugiyono, 2017). Metode penelitian yang penulis gunakan adalah metode penelitian deskriptif dan asosiatif, dengan pendekatan kuantitatif.Metode penelitian deskriptif adalah penelitian yang dilakukan untuk mengetahui nilai variabel mandiri, baik satu variabel atau lebih (variabel independen) tanpa membuat perbandingan, atau menghubungkan dengan variabel yang lain(Sugiyono, 2017). Sedangkan metode penelitian asosiatif merupakan penelitian yang bertujuan untuk mengetahui pengaruh atau hubungan antara dua variabel atau lebih, dgunakan teori yang dapat menjelaskan, meramalkan dan mengontrol suatu gejala(Sugiyono, 2010). Kemudian penelitian kuantitatif dapat diartikan sebagai metode penelitian yang berlandaskan pada filsafat positivisme, digunakan untuk meneliti pada populasi atau sampel tertentu, pengumpulan data dengan menggunakan instrument penelitian, analisis data bersifat kuantitatif/statistik, dengan tujuan untuk menguji hipotesis yang telah ditetapkan(Sugiyono, 2017).

\subsection{Populasi dan Teknik Penarikan Sampel}

\subsubsection{Populasi}

Populasi bukan hanya orang, tetapi juga obyek dan benda - benda alam yang lain. Populasi juga bukan sekedar jumlah yang ada pada subyek atau obyek yang dipelajari, tetapi meliputi seluruh karakteristik atau sifat yang dimiliki oleh subyek atau sifat itu. Populasi adalah wilayah generalisasi yang terdiri atas objek/subjek yang memiliki kualitas atau karakteristik tertentu yang ditetapkan oleh peneliti untuk dipelajari dan kemudian ditarik kesimpulannya(Sugiyono, 2014). Populasi dari penelitian ini adalah seluruh karyawan PT. Rismawan Pratama Bersinar Sukabumi sebanyak 92 orang karyawan.

\subsubsection{Teknik Penarikan Sampel}

Sampel merupakan bagian dari populasi.Sampel adalah bagian dari jumlah dan karakteristik yang dimiliki oleh populasi tersebut, apa yang dipelajari dari sampel kesimpulannya akan dapat diberlakukan untuk populasi sehingga sampel yang di ambil harus betul - betuk representative atau mewakili(Sugiyono, 2014). Teknik pengambilan merupakan cara pengambilan sample sesuai dengan keadaan atau sesuai dengna yang dibutuhkan. Untuk sekedar ancer-ancer maka apabila subjeknya kurang dari 100 lebih baik diambil semua sehingga penelitiannya merupakan penelitian populasi (sensus)(Suharsimi, 2013)".Dengan demikian maka jumlah responden yang diteliti sebanyak jumlah populasi yaitu 92 orang karyawan PT. Rismawan Pratama Bersinar Sukabumi.

\subsection{Metode Pengumpulan Data}

Teknik pengumpulan data merupakan langkah yang paling penting dalam penelitian karena tujuan utama dari penelitian adalah mendapatkan data(Sugiyono, 2016).

Jenis data yang diperlukan dalam penelitian ini adalah :

1. Data primer, di peroleh dari menyebarkan kuisioner berupa daftar pertanyaan dengan menggunakan skala likert yang di sebarkan kepada seluruh sampel dalam penelitian ini.

2. Data Sekunder, diperoleh melalui laporan dokumen perusahaan, informasi langsung karyawan perusahaan, melalui penelitian terdahulu yang dilakukan oleh pihak lain dan buku - buku yang berkaitan dengan masalah yang di teliti.

Data yang diproleh langsung dari jawaban kuisioner merupakan data primer yang penting untuk menjawab masalah dan menguji hipotesis.

\subsection{Operasionalisasi Variabel}

Variabel penelitian adalah suatu hal yang berbentuk apa saja yang diterapkan oleh peneliti untuk dipelajari sehingga diperoleh informasi tentang hal tersebut, kemudian ditarik kesimpulan(Sugiyono, 2017). Dalam memudahkan penelitian dan untuk lebih terfokus pada sasaran 
dan tujuan penelitian, maka Variabel yang digunakan penelitian ini adalah variabel tidak bebas (Variabel dependen) yaitu kinerja karyawan (Y), sedangkan variabel bebas (Variabel independen) yaitu kecerdasan emosional $\left(\mathrm{X}_{1}\right)$ dan komitmen organisasi $\left(\mathrm{X}_{2}\right)$.

Untuk lebih jelasnya maka batasan dari variabel-variabel tersebut dapat kita lihat pada tabel operasional variabel berikut ini:

Tabel 3.1 Operasionalisasi Variabel

\begin{tabular}{|c|c|c|}
\hline Definisi & Dimensi & Skala \\
\hline $\begin{array}{l}\text { Kecerdasan Emosional }\left(\mathbf{X}_{1}\right) \\
\text { Emosi merujuk pada suatu perasaan dan pikiran } \\
\text { yang khas, suatu keadaan biologis dan psikologis } \\
\text { dan serangkaian kecenderungan untuk bertindak. } \\
\text { Emosi pada dasarnya adalah dorongan untuk } \\
\text { bertindak. } \\
\text { (Goleman dalam Gunawan, Sutadji, 2014) }\end{array}$ & $\begin{array}{l}\text { 1. Kesadaran diri (Self- } \\
\text { Awareness) } \\
\text { 2. Mengatur diri sendiri } \\
\text { (self-Regulation) } \\
\text { 3. Motivasi diri (Self- } \\
\text { Motivation) } \\
\text { 4. Memelihara hubungan } \\
\text { social (Interpersonal } \\
\text { skill) }\end{array}$ & Ordinal \\
\hline $\begin{array}{l}\text { Komitmen Organsiasi }\left(\mathbf{X}_{2}\right) \\
\text { Robbins } \quad(2014: 83) \text { komitmen organisasi } \\
\text { merupakan salah satu sikap yang merefleksikan } \\
\text { perasaan suka atau tidak suka terhadap organisasi } \\
\text { tempatnya bekerja } \\
\text { (Robins, } 2014)\end{array}$ & $\begin{array}{ll}\text { 1. } & \begin{array}{l}\text { Komitmen } \\
\text { afektif(affective }\end{array} \\
\text { commitment) } \\
\text { 2. } \\
\text { komitmen } \\
\text { berkelanjutan } \\
\text { (continuance } \\
\text { commitment) } \\
\text { 3. } \begin{array}{l}\text { komitmen normatif } \\
\text { (normative } \\
\text { commitment) }\end{array}\end{array}$ & Ordinal \\
\hline $\begin{array}{l}\text { Kinerja Karyawan (Y) } \\
\text { Kinerja seorang karyawan baik bila ia mempunyai } \\
\text { keahlian (skill) yang tinggi, bersedia bekerja } \\
\text { karena diberi gaji atau upah sesuai dengan } \\
\text { perjanjian dan mempunyai harapan (expectation) } \\
\text { masa depan yang baik. } \\
\text { (Sinambela, 2019) }\end{array}$ & $\begin{array}{l}\text { 1. Kesesuaian Kualitas } \\
\text { (Quality) } \\
\text { 2. Kuantitas (Quantity) } \\
\text { 3. Tingkat pengetahuan } \\
\text { (Job knowledge) } \\
\text { 4. Tingkat ketepatan } \\
\text { waktu (Availabilty) }\end{array}$ & Ordinal \\
\hline
\end{tabular}

Diolah sendiri (2019) 


\subsection{Metode Analisis}

\subsubsection{Uji Reliabilitas Instrumen}

$$
s^{2}=\frac{n \sum_{i=1}^{20} x_{i}^{2}\left(\sum_{i=1}^{n} x_{i}\right)^{2}}{n(n-1)}
$$

Pengujian reliabilitas konsisten internal (internal consistency) dengan menggunakan koefisien alpha Cronbach.Kriteria penilaian terhadap koefisien $\alpha$ - Cronbach adalah sebagai berikut:

\begin{tabular}{|lll|}
\hline$\alpha<0,6$ & $:$ & Kurang reliable \\
$0,6<\alpha<0,8$ & $:$ & Cukup reliable \\
$\alpha>0,8$ & $:$ & Sangat reliable \\
\hline
\end{tabular}

(Sekaran, 2006)

Dalam penelitian ini analisis perhitungannya menggunakan bantuan program statistik SPSS Windows versi 25.

\subsubsection{Uji Validitas Instrumen}

$$
r_{x y}=\frac{N \sum X Y-\left(\sum X\right)\left(\sum Y\right)}{\sqrt{\left\{N \sum X^{2}-\left(\sum X^{2}\right)\right\}\left\{N \sum Y^{2}-\left(\sum Y^{2}\right)\right\}}}
$$

(Suharsimi, 2013)

Kriteria validasi adalah jika koefisien korelasi bernilai > 0,3, maka butir dinyatakan valid.

\subsubsection{Uji Asumsi Klasik}

Sebelum dilakukan pengujian analisis regresi linear berganda terhadap hipotesis penelitian, maka terlebih dahulu perlu dilakukan suatu pengujian untuk mengetahui ada atau tidaknya pelanggaran terhadap asumsi-asumsi klasik Hasil pengujian hipotesis yang baik tidak melanggar asumsi-asumsi klasik. Beberapa asumsi klasik yang harus dipenuhi terlebih dahulu sebelum menggunakan analisis regresesi linear berganda sebagai alat untuk menganalisis pengaruh variabelvariabel yang diteliti, terdiri atas: Model regresi linear berganda dikatakan baik jika data terbebas dari asumsi-asumsi klasik, baik normalitas, multikolinearitas, dan heteroskedastisitas. Namun dalam penelitian ini hanya satu uji asum klasik yang tidak boleh dilanggar yaitu uji multikolinearitas. Ada satu uji asumsi klasik yang tidak dapat dilanggar dalam mengaplikasikn analisis, yaitu uji multikolinearitas, pelanggaran terhadap asumsi ini akan menjadikan hasil estimasi parameter model kurang dapat dipercaya (Kusnendi, 2008).

\subsubsection{Analisis Statistik Deskriptif}

Untuk mengetahui deskripsi strategi pemasaran dan kualitas pelayanan serta pelanggan adalah melalui analisis deskriptif.Adapun perhitungan yang digunakan adalah analisis frekuensi skor jawaban, dimana jumlah skor dihitung.

$$
\sum \mathbf{X}=\sum(\mathbf{F i} \mathbf{x} \mathbf{B})
$$


Dimana: $B=$ Bobot/skor jawaban; $F i=$ Banyaknya pernyataan/pertanyaan; $X=$ Variabel pertanyaan

\subsubsection{Analisis Korelasi}

Korelasi product momment digunakan untuk mencari hubungan dan membuktikan hipotesis hubungan dua variabel atau lebih bila data kedua variabel atau lebih berbentuk interval atau rasio. Dan sumber data dari dua variabel atau lebih adalah sama(Sugiyono, 2016).

Koefisien korelasi pearson dirumuskan sebagai berikut:

$$
r x y=\frac{n \sum x_{i} y_{i}-\left(\sum x_{i}\right)\left(\sum y_{i}\right)}{\sqrt{\left(n \sum x_{i}^{2}-\left(x_{i}\right)^{2}\right)\left(n \sum y_{i}-\left(y_{i}\right)^{2}\right)}}
$$

Pada hakikatnya, nilai koefisien korelasi $(r)$ selalu terletak antara -1 dan +1 atau $1<\mathrm{r}<+1$, dimana bila: $\mathrm{r}_{\mathrm{x} 1, \mathrm{x} 2, \mathrm{y}}=+1$ : Menunjukkan bahwa terdapat korelasi positif sempurna antara $\mathrm{X}_{1}$ dan $\mathrm{X}_{2}$ danY. Dalam arti, makin besar harga X makin besar pula harga $Y$, dan sebaliknya, makin kecil harga $\mathrm{X}$ maka makin kecil pula harga $\mathrm{Y} . \mathrm{r}_{\mathrm{x} 1, \mathrm{x} 2, \mathrm{y}}=-1$ : Menunjukkan bahwa terdapat korelasi negatif sempurna antara variabel $\mathrm{X}$ dan variabel $\mathrm{Y}$. Dalam arti, makin besar harga $\mathrm{X}$, makin kecil harga $\mathrm{Y}$, atau sebaliknya, makin kecil harga $\mathrm{X}$ makin besar harga $\mathrm{Y} . \mathrm{r}_{\mathrm{x} 1, \mathrm{x} 2, \mathrm{y}}=0$ : Menunjukkan bahwa tidak ada korelasi antara variabel $\mathrm{X}$ dan variabel $\mathrm{Y}$.

\subsubsection{Koefisien Determinasi $(K D)$}

$$
K D=r^{2} x 100
$$

Dimana: $K D=$ koefisien determinasi dan $r \quad=$ koefisein korelasi

\subsubsection{Analisis Regresi Linier Berganda}

Untuk analisis regresi yang digunakan dalam penelitian ini menggunakan model regresi ganda.Regresi ganda adalah analisis regresi ganda digunakan oleh peneliti, bila peneliti bermaksud meramalkan bagaimana keadaan (naik turunnya) variabel dependen (kriterium), bila dua atau lebih variabel independen sebagai faktor prediktor dimanipulasi (dinaik-turunkan nilainya)(Sugiyono, 2014).

Regresi linier berganda digunakan untuk menguji pengaruh lebih dari satu independent variable terhadap dependent variable(Mustafa EQ dan Wijaya, 2013). Analisis regresi linear berganda digunakan peneliti dengan maksud untuk mengetahui sejauh mana pengaruh kecerdasan emosional dan komitmen organisasi terhadap kinerja karyawan. Bentuk persamaan dari regresi linier berganda ini adalah sebagai berikut:

$$
Y=a+b_{1} X_{1}+b_{2} X_{2}+\varepsilon
$$

Keterangan : $Y=$ Kinerja karyawan; $a=$ Koefisien konstanta; $b_{1} b_{2}=$ Koefisien regresi; $X_{1}=$ Kecerdasan emosional; $X_{2}=$ Komitmen organisasi; $\varepsilon=$ Error, variabel gangguan (Sugiyono, 2016) 


\subsubsection{Hipotesis Statistik}

\subsubsection{Uji t}

Untuk melihat hubungan dari kedua jenis variabel yang diteliti yaitu variabel $\mathrm{X}$ dan variabel $\mathrm{Y}$, maka dilakukan pengujian hipotesis.Untuk pengujian hipotesis ini penulis menggunakan uji dua pihak. Adapun rumus yang digunakan untuk menguji hipotesis nol dan hipotesis alternatif ditolak atau diterima adalah uji $\mathrm{t}($ Sugiyono, 2017), dengan rumus:

$$
t=\frac{r \sqrt{n-2}}{\sqrt{1-r^{2}}}
$$

Keterangan: $t$ : Statistik Uji Korelasi; $r$ : Koefisien Korelasi; $n:$ Jumlah Sampel

Hasil dari perhitungan statistik uji $\mathrm{t}\left(\mathrm{t}_{\text {hitung }}\right.$ ) tersebut selanjutnya dibandingkan dengan $\mathrm{t}$ tabel. Dengan $d k=n-2$ dan tingkat signifikannya yaitu $5 \%(=0,05)$, artinya jika hipotesis 0 (nol) ditolak dengan taraf kepercayaan 95\%, maka kemungkinan bahwa hasil dari penarikan kesimpulan mempunyai kebenaran 95\% dan hal ini menunjukkan adanya hubungan (korelasi) yang meyakinkan (signifikan) antara dua variabel tersebut. Untuk mengetahui ditolak atau tidaknya dinyatakan dengan kriteria sebagai berikut:

1. Jika $t_{\text {hitung }}>t_{\text {tabel}}$, maka $\mathrm{H}_{0}$ ada di daerah penolakan, berarti $\mathrm{H}_{\mathrm{a}}$ diterima artinya terdapat pengaruh antara kecerdasan emosional dan komitmen organisasi terhadap kinerja karyawan pada PT. Rismawan Pratama Bersinar Sukabumi.

2. Jika $\mathrm{t}_{\text {hitung }}<\mathrm{t}$ tabel, maka $\mathrm{H}_{0}$ ada di daerah penerimaan, berarti $\mathrm{H}_{\mathrm{a}}$ ditolak, artinya tidak terdapat pengaruh kecerdasan emosional dan komitmen organisasi terhadap kinerja karyawan pada PT. Rismawan Pratama Bersinar Sukabumi..

\subsubsection{Uji F}

Uji statistic $F$ pada dasarnya menunjukkan apakah semua variabel independen yang dimasukkan dalam model mempunyai pengaruh secara bersama - sama terhadap variabel dependen(Ghozali, 2016). Untuk menguji kedua hipotesis ini digunakan uji statistik F:

1) Taraf signifikan $\alpha=0,05$

2) Kriteria pengujian dimana Ha diterima apabila $p$ value $<\alpha$ dan $H_{a}$ ditolak apabila $p$ value $>\alpha$.

\subsubsection{Rumusah Hipotesis Statistik}

Adapun hipotesis statistik ayang akan di uji $\mathrm{t}$ dan uji $\mathrm{F}$ sebagaimana disebutkan diatas, dirumuskan sebagai berikut :

1. $\mathrm{H}_{0}: \mathrm{r}_{\mathrm{yx} 1}=0:$ Tidak terdapat pengaruh signifikan kecerdasanemosional terhadap kinerja karyawan $\mathrm{H}_{\mathrm{a}}: \mathrm{r}_{\mathrm{yx} 1} \neq 0$ : Terdapat pengaruh signifikan kecerdasan emosional terhadap kinerja karyawan

2. $\mathrm{H}_{0}: \mathrm{r}_{\mathrm{yx} 2}=0:$ Tidak terdapat pengaruh signifikan komitmen organisai terhadap kinerja karyawan $\mathrm{H}_{\mathrm{a}}: \mathrm{r}_{\mathrm{yx} 2} \neq 0$ : Terdapat pengaruh signifikan komitmen organisasi terhadap kinerja karyawan

3. $\mathrm{H}_{0}: \mathrm{r}_{\mathrm{y} 1 \times 2}=0$ : Tidak terdapat pengaruh signifikan kecerdasan emosional dan dan komitmen organisasi secara bersama-sama terhadap kinerja karyawan

4. $\mathrm{H}_{\mathrm{a}}: \mathrm{r}_{\mathrm{y} 1 \times 2} \neq 0$ : Terdapat pengaruh signifikan kecerdasan emosional dan dan komitmen organisasi secara bersama-sama terhadap kinerja karyawan 


\section{HASIL DAN DISKUSI}

\subsection{Uji Validitas Kecerdasan Emosional}

Uji validitas Kecerdasan Emosional $\left(\mathrm{X}_{1}\right)$ dilakukan terhadap 12 indikator kecerdasan emosional dengan data sampel sebanyak $(n)=92$ responden (karyawan) yang dapat dilihat dalam tabel perhitungan dengan menggunakan alat bantu IBMSPSS Statistics Program Version 25.0. Kriteria validasi adalah jika koefisien korelasi bernilai > 0,3, maka butir dinyatakan valid, angka 0,3 merupakan nilai kritis validitas data dengan $\alpha$ (alpha) 5\%. Berdasarkan hasil perhitungan analisis pearson correlate bivariate, maka uji validitas instrumennya dapat dilihat pada tabel dibawah ini:

Tabel 4.1Uji Validitas Instrumen

Kecerdasan Emosional (Variabel $\mathbf{X}_{1}$ )

\begin{tabular}{|c|c|c|c|}
\hline Pernyataan & $\boldsymbol{r}$ Dengan Rata-Rata & Nilai Kritis & Keterangan \\
\hline 1 & 0.422 & 0.3 & Valid \\
\hline 2 & 0.475 & 0.3 & Valid \\
\hline 3 & 0.718 & 0.3 & Valid \\
\hline 4 & 0.581 & 0.3 & Valid \\
\hline 5 & 0.632 & 0.3 & Valid \\
\hline 6 & 0.360 & 0.3 & Valid \\
\hline 7 & 0.751 & 0.3 & Valid \\
\hline 8 & 0.570 & 0.3 & Valid \\
\hline 9 & 0.652 & 0.3 & Valid \\
\hline 10 & 0.671 & 0.3 & Valid \\
\hline 11 & 0.611 & 0.3 & Valid \\
\hline 12 & 0.488 & 0.3 & Valid \\
\hline
\end{tabular}

Nilai kritis (r) di ambil dari tabel kritis 0,3 pada $n=92$ dan $\alpha$ 0,05 (5\%)

Berdasarkan hasil uji validitas instrumen kecerdasan emosional tersebut, maka responden dapat menjawab semua butir pernyataan. Dimana hasilnya dari 12 pernyataan indikator dinyatakan valid, artinya ke-12 pernyataan tersebut dapat mengukur apa yang hendak di ukur yaitu mengukur kecerdasan emosional.

\subsubsection{Uji Validitas Komitmen Organiasi}

Tabel 4.2 Uji Validitas Instrumen

Komitmen Organisasi (Variabel $\mathbf{X}_{2}$ )

\begin{tabular}{|c|c|c|c|c|}
\hline \multirow{10}{*}{$\begin{array}{c}\text { Nilai } \\
\text { di ambil } \\
\text { kritis } 0,3 \\
92 \text { dan } \alpha\end{array}$} & Pernyataan & $r$ Dengan Rata-Rata & Nilai Kritis & Keterangan \\
\hline & 1 & 0.151 & 0.3 & Tidak Valid \\
\hline & 2 & 0.499 & 0.3 & Valid \\
\hline & 3 & 0.519 & 0.3 & Valid \\
\hline & 4 & 0.514 & 0.3 & Valid \\
\hline & 5 & 0.624 & 0.3 & Valid \\
\hline & 6 & 0.589 & 0.3 & Valid \\
\hline & 7 & 0.562 & 0.3 & Valid \\
\hline & 8 & 0.578 & 0.3 & Valid \\
\hline & 9 & 0.521 & 0.3 & Valid \\
\hline
\end{tabular}

kritis ( $r)$ dari tabel pada $n=$ $0,05(5 \%)$

Berdasarkan hasil uji validitas instrumen komitmen organisasi tersebut, maka responden dapat menjawab semua butir pernyataan. Dimana hasilnya dari 9 (sembilan) pernyataan indikator 
dinyatakan valid, artinya ke- 9 (sembilan) pernyataan tersebut dapat mengukur apa yang hendak di ukur yaitu mengukur komitmen organisasi.

\subsubsection{Uji Validitas Kinerja Karyawan}

Tabel 4.3Uji Validitas Instrumen

Kinerja Karyawan (Variabel Y)

\begin{tabular}{|c|c|c|c|}
\hline Pernyataan & $\boldsymbol{r}$ Dengan Rata-Rata & Nilai Kritis & Keterangan \\
\hline 1 & 0.435 & 0.3 & Valid \\
\hline 2 & 0.588 & 0.3 & Valid \\
\hline 3 & 0.582 & 0.3 & Valid \\
\hline 4 & 0.656 & 0.3 & Valid \\
\hline 5 & 0.672 & 0.3 & Valid \\
\hline 6 & 0.610 & 0.3 & Valid \\
\hline 7 & 0.591 & 0.3 & Valid \\
\hline 8 & 0.592 & 0.3 & Valid \\
\hline 9 & 0.394 & 0.3 & Valid \\
\hline 10 & 0.591 & 0.3 & Valid \\
\hline
\end{tabular}

Nilai kritis ( $r)$ di ambil dari tabel kritis 0,3 pada $n=92$ dan $\alpha 0,05(5 \%)$

Berdasarkan hasil uji validitas instrumen kinerja karyawan tersebut, maka responden dapat menjawab semua butir pernyataan. Dimana hasilnya dari 10 (sepuluh) pernyataan indikator dinyatakan valid, artinya ke-10 (sepuluh) pernyataan tersebut dapat mengukur apa yang hendak di ukur yaitu mengukur kinerja karyawan.

\subsubsection{Uji Reliabilitas}

\subsubsection{Uji Reliabilitas Kecerdasan Emosional}

Pengujian ini dapat di analisis melalui bantuan IBMSPSS Statistics Program Version 25.0, maka diperoleh nilai Alpha Corunbach's :

Tabel 4.4

Uji Reliabilitas Instrumen Kecerdasan Emosional (Variabel $\mathbf{X}_{\mathbf{1}}$ )

Case Processing Summary

\begin{tabular}{|cl|r|r|}
\hline & \multicolumn{1}{|c|}{$\mathrm{N}$} & \multicolumn{1}{c|}{$\%$} \\
\hline Cases & Valid & 92 & 100.0 \\
& Excluded $^{\mathrm{a}}$ & 0 & .0 \\
& Total & 92 & 100.0 \\
\hline
\end{tabular}

a. Listwise deletion based on all variables in the procedure.

\section{Reliability Statistics}

\begin{tabular}{|r|r|}
\hline $\begin{array}{c}\text { Cronbach's } \\
\text { Alpha }\end{array}$ & N of Items \\
\hline .807 & 12 \\
\hline
\end{tabular}

Nilai reliabilitas variabel kecerdasan emosional dari 12 item pernyataan diperoleh nilai Alpha Cronbach's $(\alpha)$ sebesar 0.807 artinya nilai reliabel sama dengan $\alpha>0.800$ yang berarti instrument 
variabel kecerdasan emosional sangat reliable artinya dapat dipercaya sebagai alat untuk mengumpulkan data atau jawaban responden yang konsisten dan seragam.

\subsubsection{Uji Reliabilitas Komitmen Organsiasi}

Tabel 4.5

Uji Reliabilitas Instrumen Komitmen Organisasi (Variabel $\mathbf{X}_{2}$ )

Case Processing Summary

\begin{tabular}{|ll|r|r|}
\hline & & \multicolumn{1}{|c|}{ N } & \multicolumn{1}{c|}{$\%$} \\
\hline Cases & Valid & 92 & 100.0 \\
& Exclude & & \\
& $\mathrm{d}^{\mathrm{a}}$ & 0 & .0 \\
& Total & 92 & 100.0 \\
\hline
\end{tabular}

a. Listwise deletion based on all variables in the procedure.

\section{Reliability Statistics}

\begin{tabular}{|r|r|}
\hline $\begin{array}{c}\text { Cronbach's } \\
\text { Alpha }\end{array}$ & N of Items \\
\hline .676 & 8 \\
\hline
\end{tabular}

Nilai reliabilitas variabel Komitmen Organisasi dari 9 item pernyataan setelah dilakukan koreksi (melakukan drop) pada satu item pernyataan yang tidak valid, sehingga hanya 8 item pernyataan komitment organisasi yang dimasukan dalam pengujian reliabilitas data, maka diperoleh nilai Alpha Cronbach's $(\alpha)$ sebesar 0.676 artinya nilai reliabel sama dengan $0.600<\alpha<0.800$ yang berarti instrument variabel Komitmen Organisasi reliable artinya dapat dipercaya sebagai alat untuk mengumpulkan data atau jawaban responden yang konsisten dan seragam.

\subsubsection{Uji Reliabilitas Kinerja Karyawan}

Tabel 4.6

Uji Reliabilitas Instrumen Kinerja Karyawan (Variabel Y)

Case Processing Summary

\begin{tabular}{|ll|r|r|}
\hline & & $\mathrm{N}$ & \multicolumn{1}{c|}{$\%$} \\
\hline Cases & Valid & 92 & 100.0 \\
& Excluded $^{\mathrm{a}}$ & 0 & .0 \\
& Total & 92 & 100.0 \\
\hline
\end{tabular}

a. Listwise deletion based on all variables in the procedure.

Nilai reliabilitas variabel Kinerja Karyawan dari 10 item pernyataan diperoleh nilai Alpha Cronbach's $(\alpha)$ sebesar 0.751 artinya bahwa nilai reliabel berasa diantara $0.600<\alpha<0.800$ yang berarti instrument variabel kinerja karyawan cukup reliable artinya dapat dipercaya sebagai alat untuk mengumpulkan data atau jawaban responden yang konsisten dan seragam. 


\subsubsection{Uji Asumsi Klasik Uji Multikolinearitas}

Uji asumsi klasik yang digunakan dalam penelitian ini adalah uji multikolinearitas. Multikolinearitas bertujuan untuk menguji apakah model regresi ditemukan adanya korelasi antar variabel bebas (independen). Jika variabel independen saling berkorelasi, maka variabel-variabel ini tidak ortogonal. Variabel ortogonal adalah variabel independen yang nilai korelasi antar sesama variabel independen sama dengan nol.

Tabel 4.7Hasil Uji Multikolinieritas

\begin{tabular}{|c|c|c|c|c|c|c|}
\hline \multirow[b]{2}{*}{ Model } & \multicolumn{2}{|c|}{$\begin{array}{l}\text { Unstandardized } \\
\text { Coefficients }\end{array}$} & \multirow{2}{*}{$\begin{array}{c}\begin{array}{c}\text { Standardized } \\
\text { Coefficients }\end{array} \\
\text { Beta }\end{array}$} & \multicolumn{2}{|c|}{$\begin{array}{l}\text { Collinearity } \\
\text { Statistics }\end{array}$} & $\begin{array}{l}\text { Variable: } \\
\text { Kineria }\end{array}$ \\
\hline & $\mathrm{B}$ & Std. Error & & Tolerance & VIF & Karyawa \\
\hline $\begin{array}{ll}1 & \text { (Constant) }\end{array}$ & 3.787 & 1.995 & & & & \\
\hline Strategi Pemasaran & .527 & .065 & .650 & .341 & 2.931 & $\begin{array}{l}\text { mber }: \text { Da } \\
\text { SPSS } 25.0\end{array}$ \\
\hline Kualitas Pelayanan & .308 & .086 & .286 & .341 & 2.931 & Diolah \\
\hline
\end{tabular}

2019)

Berdasarkan tabel hasil Uji Multikolinieritas, nilai tolerance variabel kecerdasan emosional $\left(X_{1}\right)=0,341$ dan komitmen organsiasi $\left(X_{2}\right)=0,341$ lebih besar dari 0,10 (tolerance $>0,10$ ), ini menunjukkan bahwa dalam penelitian ini tidak terdapat masalah dalam uji multikolinieritas. Demikian juga dengan nilai VIF variabel kecerdasan emosional $\left(\mathrm{X}_{1}\right)=2,931$ dan komitmen organisasi $\left(\mathrm{X}_{2}\right)=2,931$ lebih kecil dari 10,00 (VIF< 10,00), maka dapat disimpulkan bahwa tidak terjadi multikolinieritas antara variabel independen dalam model regresi.

\subsubsection{PengaruhKecerdasan Emosional dan Komitmen Organisasi Terhadap Kinerja Karyawan}

Agar dapat menjelaskan pengaruh kecerdasan emosional dan komitmen organisasi terhadap kinerja karyawan, terlebih dahulu harus diketahui hubungan antara data kecerdasan emosional $\left(\mathrm{X}_{1}\right)$, komitmen organisasi $\left(\mathrm{X}_{2}\right)$ dan kinerja karyawan $(\mathrm{Y})$.

\subsubsection{Analisis Koefisien Korelasi Pearson Product Moment}

Untuk mengetahui seberapa besar hubungan pengaruh kecerdasan emosional dan komitmen organisasi terhadap kinerja karyawan, data-data yang telah di peroleh selama penelitian akan di analisis dengan menggunakan metode analisis korelasi Pearson Product Moment.

Tabel 4.8Output SPSS Korelasi Pearson Variabel $\mathrm{X}_{1}, \mathrm{X}_{2}$ dan Variabel $\mathrm{Y}$

\begin{tabular}{|c|c|c|c|c|}
\hline \multicolumn{5}{|c|}{ Correlations } \\
\hline & & $\begin{array}{c}\text { Kecerdasan } \\
\text { Emosional }\end{array}$ & $\begin{array}{l}\text { Komitmen } \\
\text { Organisasi }\end{array}$ & $\begin{array}{c}\text { Kinerja } \\
\text { Karyawan }\end{array}$ \\
\hline \multirow{3}{*}{$\begin{array}{l}\text { Kecerdasan } \\
\text { Emosional }\end{array}$} & Pearson Correlation & 1 & $.812^{* *}$ & $.882^{* *}$ \\
\hline & Sig. (2-tailed) & & .000 & .000 \\
\hline & $\mathrm{N}$ & 92 & 92 & 92 \\
\hline \multirow{3}{*}{$\begin{array}{l}\text { Komitmen } \\
\text { Organisasi }\end{array}$} & Pearson Correlation & $.812^{* *}$ & 1 & $.813^{* *}$ \\
\hline & Sig. (2-tailed) & .000 & & .000 \\
\hline & $\mathrm{N}$ & 92 & 92 & 92 \\
\hline \multirow{3}{*}{$\begin{array}{l}\text { Kinerja } \\
\text { Karyawan }\end{array}$} & Pearson Correlation & $.882^{* * *}$ & $.813^{* *}$ & 1 \\
\hline & Sig. (2-tailed) & .000 & .000 & \\
\hline & $\mathrm{N}$ & 92 & 92 & 92 \\
\hline
\end{tabular}

Berdasa

kan hasil analisa dengan uji Correlation Pearson's seperti terlihat pada tabel di atas, maka:

1. Dapat dilihat nilai korelasi (hubungan) Kecerdasan 
Emosional $\left(\mathrm{X}_{1}\right)$ dengan Kinerja Karyawan (Y) sebesar $r=0.882$ yang berarti berada diantara nilai $0,800-1,000$, yang artinya memiliki hubungan sangat kuat dan searah. Sifat hubungan positif yang artinya jika Kecerdasan Emosional meningkat maka Kinerja Karyawan akan semakin meningkat pula. begitupula sebaliknya.

2. Dapat dilihat nilai korelasi (hubungan) Komitment Organisasi $\left(\mathrm{X}_{2}\right)$ dengan Kinerja Karyawan (Y) sebesar $r=0.813$ yang berarti berada diantara nilai $0,800-0,100$, yang artinya memiliki hubungan sangat kuat dan searah. Sifat hubungan positif yang artinya jika Komitmen Organisasi bertambah atau meningkat maka Kinerja Karyawan akan semakin bertambah atau meningkat pula, begipula sebaliknya.

\subsubsection{Analisis Koefisien Determinasi (KD) Analisis Regresi Linear Berganda}

\subsection{Perhitungan dan Analisis Koefisien Determinasi $(K D)$}

Selain menggunakan Regresi Linear dan Korelasi Pearson, besarnya konstribusi pengaruh dari kecerdasan emosional $\left(\mathrm{X}_{1}\right)$ dan komitmen organisasi $\left(\mathrm{X}_{2}\right)$ terhadap kinerja karyawan $(\mathrm{Y})$ tersebut dapat dianalisis dengan menggunakan metode Koefisien Determinasi $(K D)$.

Nilai Koefisien Determinasi $(K D)$ dengan $R^{\text {Square }}\left(R^{2}\right)$ dapat dihitung dengan bantuan program IBM SPSS Statistics Version 25.0. Berikut penulis sajikan tabel keofisen determinasi output SPSS program:

Tabel 4.9

Koefisien Determinasi $\left(\mathbf{R}^{2}\right)$ Model Summary ${ }^{b}$

\begin{tabular}{|l|c|r|r|c|}
\hline $\begin{array}{l}\text { Mode } \\
1\end{array}$ & $\mathrm{R}$ & $\begin{array}{c}\mathrm{R} \\
\text { Square }\end{array}$ & $\begin{array}{c}\text { Adjusted } \\
\mathrm{R} \text { Square }\end{array}$ & $\begin{array}{c}\text { Std. Error of the } \\
\text { Estimate }\end{array}$ \\
\hline 1 & $.897^{\mathrm{a}}$ & .805 & .801 & 1.46128 \\
\hline
\end{tabular}

a. Predictors: (Constant), Komitmen Organsiasi, Kecerdasan Emosional

b. Dependent Variable: Kinerja Karyawan

Berdasarkanoutput SPSS di atas, maka :

$$
\begin{aligned}
& K D=(0,897)^{2} \times 100 \\
& K D=0,805 \times 100 \\
& K D=80,5 \%
\end{aligned}
$$

Berdasarkan perhitungan di atas, maka dapat di ketahui besarnya angka koefisien determinasi $(K D)$ nya yaitu sebesar 0,805 atau $80,5 \%$. Hal ini mebeerikan makna bahwa kecerdasan emosional $\left(\mathrm{X}_{1}\right)$ dan komitmen organisasi $\left(\mathrm{X}_{2}\right)$ memberikan kontribusi pengaruh $80,5 \%$ terhadap kinerja karyawan (Y), dan sisanya sebesar 19,5\% dipengaruhi oleh variabel lainyang tidak diteliti.

\subsection{Analisis Regresi Linear Berganda}

Analisis regresi linear berganda digunakan peneliti dengan maksud untuk mengetahui sejauh mana pengaruh kecerdasan emosional dan komitmen organisasi terhadap kinerja karyawan.

Berdasarkan output SPSS yaitu tabel coeffisients ${ }^{\mathrm{a}}$, diperoleh contanta (a) adalah 3,787 sedangkan nilai koefisien regresi kecerdasan emosional $\left(b_{1}\right)$ sebesar 0,527 dan komitmen organisasi $\left(b_{2}\right)$ sebesar 0.308 , sehingga dengan demikian persamaan regresinya dapat ditulis:

$$
Y=3,787+0,527 X_{1}+0.308 X_{2}
$$


Sehingga dari persamaan regresi tersebut dapat diterjemaahkan:

1. Konstanta (a) memiliki nilai sebesar 3,787, menyatakan bahwa jika kecerdasan emosional $\left(\mathrm{X}_{1}\right)$ dan komitmen organsiasi $\left(\mathrm{X}_{2}\right)$ tidak ada kenaikan atau sama dengan nilai 0 , maka besarnya nilai kinerja karyawan (Y) sebesar 3,787.

2. Nilai koefisien regresi variabel kecerdasan emosional $\left(X_{1}\right)$ adalah sebesar 0,527 dan bertanda positif, artinya jika variabel kecerdasan emosional meningkat sebesar $1 \mathrm{kali}$,- sementara komitmen organisasi tetap atau konstan seperti saat ini, maka akan menyebabkan nilai kinerja karyawan meningkat sebesar 0,527 kali. Ini menunjukan bahwa kecerdasan emosional memiliki hubungan searah dengan kinerja karyawan.

3. Nilai koefisien regresi variabel komitmen organisasi $\left(\mathrm{X}_{2}\right)$ adalah sebesar 0,308 dan bertanda positif, artinya jika variabel komitmen organsiasi naik sebesar 1 kali,- sementara kecerdasan emosional tetap atau konstan seperti saat ini, maka akan menyebabkan nilai kinerja karyawan naik sebesar 0,308 kali. Ini menunjukan bahwa komitmen organisasi memiliki hubungan searah dengan kinerja karyawan.

\subsubsection{Pengujian Hipotesis}

\subsubsection{Uji t}

Uji t digunakan untuk mengetahui apakah dalam model regresi variabel independen secara parsial berpengaruh signifikan terhadap variabel dependen atau tidak.

\subsection{Uji Pengaruh Kecerdasan Emosional $\left(X_{1}\right)$ Terhadap Kinerja Karyawan $(Y)$}

Untuk mengetahui hasil uji t dapat dilihat pada tabel dibawah ini

Tabel 4.11

Uji t Pengaruh Kecerdasan Emosional $\left(\mathbf{X}_{1}\right)$

Terhadap

Kinerja Karyawan (Y)
Coefficients $^{\mathbf{a}}$

\begin{tabular}{|c|c|c|c|c|c|c|}
\hline \multirow[b]{2}{*}{ Model } & & \multicolumn{2}{|c|}{$\begin{array}{c}\text { Unstandardized } \\
\text { Coefficients }\end{array}$} & \multirow{2}{*}{$\begin{array}{c}\begin{array}{c}\text { Standardized } \\
\text { Coefficients }\end{array} \\
\text { Beta }\end{array}$} & \multirow[b]{2}{*}{1} & \multirow[b]{2}{*}{ Sig. } \\
\hline & & B & Std. Error & & & \\
\hline 1 & (Constant) & 5.813 & 2.033 & & 2.859 & .005 \\
\hline & $\begin{array}{l}\text { Kecerdasan } \\
\text { Emosional }\end{array}$ & .716 & .040 & .882 & 17.717 & .000 \\
\hline
\end{tabular}

a. Dependent Variable: Kinerja Karyawan

(Sumber : Data SPSS 25.0 Diolah Peneliti, 2019)

Dari tabel di atas, dapat diketahui bahwa kecerdasan emosional memiliki signifikansi $0,000<$ 0,05 lebih kecil $(\operatorname{sig}<\alpha)$ dengan taraf signifikan 0,05 , dan atau $\mathrm{t}_{\text {hitung }}>\mathrm{t}$ tabel dengan $n-k(92-2)$, sehingga diperoleh $17.717>1,662$ dengan taraf signifikansi 0,05 maka dapat disimpulkan bahwa $\mathrm{H}_{0}$ ditolak dan $\mathrm{H}_{\mathrm{a}}$ diterima. Ini artinya bahwa terdapat pengaruh yang signifikan dari kecerdasan emosional terhadap kinerja karyawan. Jadi dari kasus ini dapat disimpulkan bahwa secara parsial 
Kecerdasan Emosional berpengaruh signifikan terhadap Kinerja Karyawan pada PT. Rismawan Pratama Bersinar Sukabumi.

\subsection{Uji Pengaruh Komitmen Organisasi $\left(\mathrm{X}_{2}\right)$ Terhadap Kinerja Karyawan $(\mathrm{Y})$}

Tabel 4.12

Uji t Pengaruh Komitmen Organisasi $\left(\mathbf{X}_{2}\right)$ Terhadap Kinerja Karyawan (Y) Coefficients $^{\mathrm{a}}$

\begin{tabular}{|c|c|c|c|c|c|}
\hline \multirow[b]{2}{*}{ Model } & \multicolumn{2}{|c|}{$\begin{array}{l}\text { Unstandardized } \\
\text { Coefficients }\end{array}$} & \multirow{2}{*}{$\begin{array}{c}\text { Standardized } \\
\text { Coefficients }\end{array}$} & \multirow[b]{2}{*}{$\mathrm{t}$} & \multirow[b]{2}{*}{ Sig. } \\
\hline & B & Std. Error & & & \\
\hline 1 (Constant) & 5.775 & 2.379 & & 2.427 & .017 \\
\hline $\begin{array}{l}\text { Komitmen } \\
\text { Organisasi }\end{array}$ & .753 & .057 & .813 & 13.247 & .000 \\
\hline
\end{tabular}

a. Dependent Variable: Kinerja Karyawan

(Sumber : Data SPSS 25.0 Diolah Peneliti, 2019)

Berdasarkan tabel di atas, dapat diketahui bahwa motivasi karyawan memiliki signifikansi $0,000<0,05(\operatorname{sig}<\alpha)$ dan $\mathrm{t}_{\text {hitung }}>\mathrm{t}$ tabel dengan $\mathrm{n}-\mathrm{k}(92-2)$, sehingga diperoleh 13.247 $>1.662$, maka dapat disimpulkan maka $\mathrm{H}_{0}$ ditolak dan $\mathrm{H}_{\mathrm{a}}$ diterima, maka dapat disimpulkan bahwa $\mathrm{H}_{0}$ ditolak dan $\mathrm{H}_{\mathrm{a}}$ diterima. Ini artinya bahwa secara parsial terdapat pengaruh yang signifikan dari komitmen organisasi terhadap kinerja karyawan. Jadi dari kasus ini dapat disimpulkan bahwa secara parsial komitmen organisasi berpengaruh signifikan terhadap kinerja karyawanPT. Rismawan Pratama Bersinar Sukabumi.

\subsubsection{Uji F}

Pengujian ini bertujuan untuk menguji pengaruh variabel independen (kecerdasan emosional dan komitmen organisasi) secara simultan terhadap variabel dependen (kinerja karyawan). Diketahui bahwa signifikansi $0,000<0,05$ dan $F$ hitung $>F$ tabel dengan df $(n 1)=k-1$ dan df $(n 2)=n-k$. Sehingga $183.719>3,10$, maka $\mathrm{H}_{0}$ ditolak dan $\mathrm{H}_{1}$ diterima. Artinya ada pengaruh secara signifikan antara Kecerdasan Emosional dan Komitmen Organisasi secara bersama-sama (simultan) terhadap Kinerja Karyawan.Dengan demikian dapat disimpulkan bahwa Kecerdasan Emosional dan Komitmen Organsiasi secara bersama-sama (simultan) berpengaruh signifikan terhadap Kinerja Karyawan pada PT. Rismawan Pratama Bersinar Sukabumi.

\subsection{Pembahasan}

\subsubsection{Kecerdasan Emosional, Komitmen Organsiasi dan Kinerja Karyawan}

Berdasarkan penilaian atau analisis deskriptif hasil penelitian, maka dapat diketahui rata-rata tanggapan responden mengenai variabel kecerdasan emosional, komitmen organisasi dan kinerja karyawan yang didasarkan pada masing-masing indikator ketiga variabel tersebut secara keseluruhan responden memberikan jawaban setuju dan sangat setuju. Artinya bahwa karyawan sudah menjaga dan meningkatkan kecerdasan emosional dengan baik saat bekerja dan komitmen organisasi yang diterapkan sesuai dengan kesepatakatan antara karyawan dengan PT. Rismawan Pratama Bersinar Sukabumi serta semua karyawan menyatakan setuju dengan semua indikator tersebut dalam mendukung peningkatan kinerja mereka, sehingga dapat dikatakan bahwa kinerja karyawan karyawan sudah baik pada PT. Rismawan Pratama Bersinar Sukabumi. 


\subsubsection{Pengaruh Kecerdasan Eosional Terhadap Kinerja Karyawan}

Berdasarkan hasil pengujian hipotesis uji t (parsial), kecerdasan emosional berpengaruh secara positif dan signifikan terhadap kinerja karyawan pada PT. Rismawan Pratama Bersinar, hal tersebutdapat diketahui berdasarkan nilai $t$ tabel $(1,662)$ dan $t$ hitung kecerdasan emosional $(17,717)$, dimana ( $\mathrm{t}_{\text {hitung }}>\mathrm{t}$ tabel $)$ atau $(17,717>1,662)$ serta dapat dilihat dari nilai signifikansi $(\mathrm{sig}<\alpha)$ atau $(0,000<0,05)$, maka $\mathrm{H}_{0}$ ditolak $\left(\mathrm{H}_{\mathrm{a}}\right.$ diterima) artinya kecerdasan emosional berpengaruh secara positif dan signifikan terhadap kinerja karyawan.

PT. Rismawan Pratama Bersinar Sukabumi selalu memperhatikan kecerdasan emosional (emotional intelligent)karyawan dalam mempertahankan kontinuitas usahanyadimulai pada saat rekruitmen hingga penilaian kinerja karyawan, begitu pentingnya kecerdasan emosional yang baik dimiliki karyawan karena akan dapat membantu meningkatkan kemampuan karyawan dalam mengelola, mengontrol, mengendalikan dan mengkoordinasikan keaadan emosinya sehingga senantiasa akan tercermin dalam setiap perilaku kerjanya yang efektif sesuai dengan peraturan dan keinginan perusahaan sehingga pada akhirnya akan dapat mencapai kinerja optimal. Artinya kecerdasan emosional yang baik dimiliki karyawan dapat menjadi salah satu kunci keberhasilan perusahaan.Dimana, bahwa kemampuan Emotional Inteligence atau kecerdasan emosional adalah salah satu faktor yang dapat menentukan kesuksesan seseorang. Kecerdasan emosi menyumbang $80 \%$ dari faktor penentu kesuksesan seseorang, sedangkan $20 \%$ yang lain ditentukan oleh IQ (inteligence Quotient)(Goleman, 2000).Hasil penelitian lain membuktikan bahwa kecerdasan emosional berpengaruh signifikan terhadap kinerja karyawan(Fitriastuti, 2013).

\subsubsection{Pengaruh Komitmen Organisasi Terhadap Kinerja Karyawan}

Berdasarkan hasil pengujian hipotesis uji t (parsial), komitmen organisasi berpengaruh secara positif dan signifikan terhadap kinerja karyawan pada PT. Rismawan Pratama Bersinar, hal tersebutdapat diketahui berdasarkan nilai $t$ tabel $(1,662)$ dan $t$ hitung kecerdasan emosional $(13,247)$, dimana ( $\mathrm{t}_{\text {hitung }}>\mathrm{t}$ tabel $)$ atau $(13,247>1,662)$ serta dapat dilihat dari nilai signifikansi $(\operatorname{sig}<\alpha)$ atau $(0,000<0,05)$, maka $\mathrm{H}_{0}$ ditolak $\left(\mathrm{H}_{\mathrm{a}}\right.$ diterima) artinya komitmen berpengaruh secara positif dan signifikan terhadap kinerja karyawan.

Karyawan yang bergabung dengan PT. Rismawan Pratama Bersinar Sukabumi dituntut memiliki komitmen dalam dirinya. Hal ini dibuktikan dengan adanya kesediaan, kesepakatan dan rasa sukarela dari karyawan untuk bertindak dan melaksanakan suatu pekerjaan yang sudah menjadi kewajibannya dengan penuh rasa tanggung jawab pada diri sendiri dan pada PT. Rismawan Pratama Bersinar Sukabumi sebagai bentuk nyata dari kesetiaan atas perjanjian yang telah disepakatinya. Sehingga akan terjadi sinkronisasi dan intergasi harmonisasi yang tercipta dengan baik antara perusahaan dengan para karyawannya yang dapat melahirkan perasaan saling percaya antara kedua belah pihak yang pada akhirnya akan melahirkan gairah semangat kerja bagi karyawan untuk selalu dapat menyelesaikan pekerjaannya dengan tepat waktu dengan senantiasa berusaha meningkatkan produktifitas dan kinerjanya sesuai dengan yang diharapkan perusahaan. Artinya bahwa ada rasa saling menghargai dan mengakui antara kedua belah pihak untuk bekerja sama dalam mencapai tujuannya. Ketika hal demikian mampu terciptakan dalam suasana perusahaan, maka karyawan akan merasa betah tetap untuk bertahan dalam perusahaan dan merasa bangga menjadi bagian dari perusahaanya.Karena komitmen organisasi adalah keinginan anggota organisasi untuk mempertahankan keanggotaannya dalam organisasi dan bersedia berusaha keras bagi pencapaian tujuan.Komitmen organisasional mencakup kebanggaan anggota, kesetiaan anggota, kecerdasan akan emosional masing-masing individu, tingkah laku, dan kemauan anggota pada organisasi(Sopiah, 2008). 


\subsubsection{Pengaruh Kecerdasan Emosional dan Komitmen Organisasi Terhadap Kinerja Karyawan}

Berdasarkan hasil penelitian uji F (simultan), kecerdasan emosional dan komitmen organisasi secara bersamaan berpengaruh secara positif dan signifikan terhadap kinerja karyawan pada PT. Rismawan Pratama Bersinar Sukabumi, hal tersebutdapat diketahui dengan melihat nilai $\mathrm{F}$ tabel $(3,10)$ dan $\mathrm{F}$ hitung $(183,719)$, dimana $\left(\mathrm{F}_{\text {hitung }}>\mathrm{F}\right.$ tabel $)$ atau $(183,719>3,10)$ serta dapat dilihat dari nilai signifikansi $(\mathrm{sig}<\alpha)$ atau $(0,000<0,05)$, maka $\mathrm{H}_{0}$ ditolak $\left(\mathrm{H}_{\mathrm{a}}\right.$ diterima). Artinya terdapat pengaruh simultan yang signifikan dari kecerdasan emosional $\left(X_{1}\right)$ dan komitmen organisasi $\left(X_{2}\right)$ terhadap kinerja karyawan.

Perusahaan dipandang perlu untuk memperhatikan kecerdasan emosional dan komitmen organisasi dimulai dengan pendekatan pada proses rekruitmen yang yang baik, pengembangan dan pelatihan karyawan yang tepat sehingga dapat melahirkan karyawan yang bijaksana memiliki kemampuan mengatur dirinya secara psikologi dan emosinya maupun mengatur orang lain serta senantiasa membuat perjanjian-perjanjian yang benar-benar dapat dipahami dan diterima antara kedua belah pihak (perusahaan dan karyawan)menuju kesukesan dan keberhasilan bersama, tinggi rendahnya kecerdasan emosional dan baik buruknya komitmen organisasi yang disepakati akan sangat mempengaruhi baik buruknya kinerja karyawan.Keberhasilan suatu organisasi sangatlah dipengaruhi oleh kinerja individu karyawan.Setiap organisasi pasti selalu meningkatkan kinerja karyawan untuk mencapai tujuan. Salah satu ukuran kinerja karyawan adalah kemampuan intelektual, yang didukung dengan kemampuan menguasai, mengelola diri sendiri serta membina hubungan dengan orang lain(Fitriastuti, 2013).

\section{KESIMPULAN}

\section{Kesimpulan}

a. Berdasarkan hasil penilaian variabel kecerdasan emosional dengan 4 yang diukur dengan 12 indikator, dimana ke-12 indikator tersebut semuanya dinilai baik (setuju) oleh responden, meskipun penilaian responden tidak seluruhnya menyatakan baik (setuju). Hal ini menujukan bahwa responden menyatakan setuju dan sudah menjaga dan meningkatkan kecerdasan emosional dengan baik saat bekerja pada PT. Rismawan Pratama Bersinar Sukabumi.

b. Berdasarkan hasil penilaian variabel komitmen organsiasi dengan 3 dimensi yang diukur melalui 9 indikator, dimana ke-9 indikator dari variabel motivasi karyawan yang dinilai baik (setuju) oleh responden. Hal ini menunjukan bahwa semua indikator dari variabel komitmen organsiasi sudah baik dan karyawan menyatakan setuju dengan semua indikator tersebut, sehingga dengan demikian dapat disimpulkan bahwa komitmen organisasi yang diterapkan sesuai dengan kesepatakatan antara karyawan dengan PT. Rismawan Pratama Bersinar Sukabumi.

c. Berdasarkan hasil penilaian variabel kinerja karyawan dengan 4 dimensi yang diukur dengan 10 indikator, dimana hanya ke-10 indikator dari variabel kinerja karyawan dinilai baik (setuju) oleh responden. Hal ini menunjukan bahwa semua indikator dari variabel kinerja karyawan sudah baik dan responden (karyawan) menyatakan setuju dengan semua indikator tersebut dalam mendukung peningkatan kinerja mereka, sehingga dapat dengan demikian dikatakan bahwa kinerja karyawan karyawan sudah baik pada PT. Rismawan Pratama Bersinar Sukabumi.

1. Pengaruh kecerdasan emosional terhadap kinerja karyawan pada PT. Rismawan Pratama Bersinar Sukabumi. Dari hasil penelitian yang telah dilakukan peneliti menunjukan bahwa pengaruh kecerdasan emosional terhadap kinerja karyawan sebesar 0,882 atau 88,2\%, yang artinya 
hubungan kedua variabel berada pada tingkat hubungan sangat kuat (significant) dan searah (positif). Artinya terjadi hubungan linear atau dengan kata lain dapat diartikan apabila kecerdasan emosional meningkat maka kinerja karyawanakan semakin meningkat pula pada PT. Rismawan Pratama Bersinar Sukabumi, begitu pula sebaliknya. Besarnya kontribusi pengaruh kecerdasan emosional terhadap kinerja karyawan sebesar $=0,777$ atau $77,7 \%$, dan sisanya $22,3 \%$ dipengaruhi oleh variabel lain yang tidak diteliti.

2. Pengaruh komitmen organsiasi terhadap kinerja karyawan pada PT. Rismawan Pratama Bersinar Sukabumi. Dari hasil penelitian yang telah dilakukan peneliti menunjukan bahwa pengaruh komitmen organsiasi terhadap kinerja karyawan sebesar 0,813 atau 81,3\%, yang artinya hubungan kedua variabel berada pada tingkat hubungan sangat kuat (significant) dan searah (positif). Artinya terjadi hubungan linear atau dengan kata lain dapat diartikan apabila komitmen organsiasi meningkat maka kinerja karyawanakan meningkat pula pada PT. Rismawan Pratama Bersinar Sukabumi, begitu pula sebaliknya. Besarnya kontribusi pengaruh komitmen organsiasi terhadap kinerja karyawan sebesar $=0,661$ atau $66,1 \%$, dan sisanya 33,9\% dipengaruhi oleh variabel lain yang tidak diteliti.

3. Pengaruh kecerdasan emosional dan komitmen organsiasi terhadap kinerja karyawan pada PT. Rismawan Pratama Bersinar Sukabumi. Dari hasil penelitian yang telah dilakukan peneliti menunjukan bahwa pengaruh emosional dan komitmen organsiasi terhadap kinerja karyawan sebesar 0,897 atau $89,7 \%$, yang artinya hubungan ketiga variabel berada pada tingkat hubungan sangat kuat (significant) dan searah (positif). Artinya terjadi hubungan linear atau dengan kata lain dapat diartikan apabila kecerdasan emosional dan komitmen organisasi baik dan meningkat maka kinerja karyawanakan baik dan meningkat pula pada PT. Rismawan Pratama Bersinar Sukabumi, begitu pula sebaliknya. Besarnya kontribusi pengaruh kecerdasan emosional dan komitmen organsiasi terhadap kinerja karyawan sebesar $=0,805$ atau 80,5\%, dan sisanya 19,5\% dipengaruhi oleh variabel lain yang tidak diteliti.

\section{Saran}

1. Untuk kecerdasan emosional, komitmen organsiasi dan kinerja karyawan:

a. Kecerdasan emosional karyawan dapat lebih ditingkatkan melalui sosialisasi pemebrian pemahaman tetntang bagaimana mengelola emosi, menangani emosi dalam melaksanakan tugas dengan menjaga kepercayaan diri karyawan dengan baik.

b. Komitmen organsiasi dapat lebih disesuaikan dengan membuat kesepakatan bersama antara perusahaan dengan karyawan, dimana segala ketentuan organisasi di atas segalanya tanpa mengesampingkan tujuan dan kebutuhan para karyawannya.

c. Kinerja karyawan agar dapat lebih ditingkatkan lagi melalui dimensi dan indikator-indikator kinerja kryawan, terutama mengenai pencapaian hasil dan jumlah target pekerjaan yang sesuai dengan standar mutu yang telah ditetapkan perusahaan, menempatkan dan memberikan tugas kepada karyawan sesuai dengan keterampilannya serta menetapkan target sesuai dengan waktu yang tersedia.

2. Hendaknya perusahaan mengetahui dan memahami kendala-kendala yang dihadapi oleh karyawan, yang mengganggu tingkat kecerdasan dan mengganggu kesadaran karyawan dalam bekerja. Karyawan diberikan kepercayaan dalam mengambil keputusannya sehingga karyawan tidak merasa tertekan dalam melaksanakan pekerjaannya. Sehingga ketika karyawan diberi kebebasan dalam mengambil keputusan sesuai dengan kecerdasannya dan kesadaran yagn normal dan juga sesuai peraturan perusahaan maka diharapkan kinerjanya akan semakin meningkat.

3. Sudah seharusnya manajemen perusahaan mengetahui dan memahami keinginan-keinginan karyawan bekerja disuatu organisasi. Komitmen dapat dibuat sesuai dengan kesepakatan antara 
kedua belah pihak (perusahaan dan para karyawan), sehingga mampu menimbulkan keterikatan emosional karyawan yang mengutamakan tujuan organisasi paling utama.

4. Berdasarkan hasil penelitian yang menunjukan adanya pengaruh yang signifikan antara kecerdasan emosional dan komitmen organsiasi terhadap kinerja karyawan pada PT. Rismawan Pratama Bersinar Sukabumi, bahwa manajemen perusahaan dipandang perlu memberikan fokus perhatian menganai hal-hal yang menghambat terjaga dan terciptanya kecerdasan emosional karyawan yang baik, meningkat jalinan komunikasi diantara para karyawan, memneuhi keinginan dan kebutuhan karyawan sesuai dengan dengan perjanjian kedua belah pihak. Dengan demikian ada sinkronisasi kecerdasan emosional dan komitmen organsaisi yang baik, yang diinginkan karyawan yang menyelaraskan kepentingan perusahaan dengan kepentingan para karyawan.

\section{REFRENSI}

Fitriastuti, T. (2013) 'Pengaruh Kecerdasan Emosional, Komitmen Organisasional Dan Organizational Citizenship Behavior Terhadap Kinerja Karyawan', Jurnal Dinamika Manajemen.

Ghozali, I. (2016) 'Aplikasi Analisis Multivariete Dengan Program IBM SPSS 23 (Edisi 8). Cetakan ke VIII', in Penelitian. doi: 10.1021/ol7029646.

Goleman, D. (2000) Kecerdasan emosional: Mengapa EI lebih penting daripada IQ, Gramedia Pustaka Utama.

Indra Gunawan, H. Sutadji, E. R. (2014) 'PENGARUH KECERDASAN EMOSIONAL DAN KOMITMEN ORGANISASI TERHADAP KINERJA PEGAWAI DINAS PERKEBUNAN DAN KEHUTANAN KABUPATEN KUTAI KARTANEGARA', eJournal Administrative Reform, 2(2), p. 13. Available at: ar.mian.fisip-unmul.ac.id\%0D.

Kusnendi (2008) Persamaan Struktual Satu dan Multigroup Sampel dengan Lisrel. Bandung: CV. Alfabeta.

Mustafa EQ, Z. and Wijaya, T. (2013) Panduan Teknik Statistik SEM \&amp; PLS dengan SPSS AMOS. Cahaya Atma.

Rani, I. H. and Mayasari, M. (2016) 'Pengaruh Penilaian Kinerja Terhadap Kinerja Karyawan Dengan Motivasi Sebagai Variabel Moderasi’, Penilain Kinerja. doi: S0168-3659(05)00367-6 [pii] 10.1016/j.jconrel.2005.08.005.

Robins, stephen. p. (2014) 'Teori Budaya Organisasi', in perilaku organisasi.

Sekaran, U. (2006) Research Methods for Business, Metodologi Penelitian untuk Bisnis. Buku 1, Edisi 4. Buku 1. Jakarta: Salemba Empat.

Sinambela, L. P. (Prof. D. (2019) Manajemen Sumber Daya Manusia, PT.Bumi Aksara.

Sopiah (2008) 'Budaya organisasi, komitmen organisasional pimpinan dan pengaruhnya terhadap kepuasan kerja dan kinerja karyawan bank', Jurnal Keuangan dan Perbankan.

Sugiyono (2010) 'Metode Penelitian Bisnis. Pendekatan Kuantitatif, kualitatif dan R \& D', Bandung: Alfabeta.

Sugiyono (2014) 'Metode penelitian', Metode Penelitian. 
Sugiyono (2016) Metodologi Penelitian Kuantitatif, Kualitatif, dan R\&D, CV Alfabeta. doi: https://doi.org/10.3929/ethz-b-000238666.

Sugiyono (2017) 'Metode Penelitian Bisnis (Pendekatan Kuantitatif, Kualitatif, Kombinasi dan R\&D)', in Metodelogi Penelitian. Bandung: Alfabeta, p. 334. Available at: www.alfabeta.com.

Sugiyono, P. D. (2014) 'Populasi dan sampel', Metode Penelitian Kuantitatif, Kualitatif dan R\&D.

Suharsimi, A. (2013) 'Prosedur Penelitian : Suatu Pendekatan Praktik (Edisi Revisi)', Jakarta: Rineka Cipta. doi: 10.1017/CBO9781107415324.004.

Supardi, E. (2016) 'PENGEMBANGAN KARIR KONTRIBUSINYA TERHADAP KINERJA PEGAWAI', Jurnal Geografi Gea. doi: 10.17509/gea.v9i1.1680.

https://www.google.com/search?safe $=$ strict \&ei=50DoXJ2_I4fb9QPW04HwAg\&q=pt+rismawan $+p r$ atama + bersinar + sukabumi \&oq $=P T$. + Rismawa\&gs_l $l=p s y$ ab.1.1.0i203j0i22i30l2.122448.125229..127404...0.0..0.312.2072.0j7j3j1.....0....1..gwswiz.......35i39i19j0i324j0i3j35i39j38j0i19j0i10i203j0i22i30i19.NFD80jPtnIs 